Review Article

\title{
A. MUKTI ALI'S THINKING IN INDONESIAN ISLAMIC EDUCATION POLICY
}

\author{
Faisal Zuhri
}

Received: 10.01.2021

Revised: 11.02.2021

Accepted: 25.02.2021

Abstract

The purpose of this study is to describe the implications of Mukti Ali's thinking in Islamic education policies in Indonesia. This study uses a qualitative method of literature. This study concludes that Mukti Ali's policy thinking includes: a) Improving Islamic educational institutions, b) Modernizing Islamic boarding schools, c) Reforming Islamic higher education institutions or state Islamic religious institutes, d) IAINing the quality of education. Mukti Ali used an integral and interdepamental approach in determining Islamic education policies while serving as Minister of Religion. The 3 ministerial decree issued during the time of the minister of religion Mukti Ali was developed in 1986 through the MAN-PK pilot project, so that Islamic education, especially madrasas, began to appear. In the following year, UUSPN No. 2 of 1989 until UUSPN No. 20 of 2003 became the basis for policies that emphasized that religious education had the right to be received by every student at the elementary, secondary and tertiary levels.

Keywords: thoughts, educational policies, Islamic educational institutions.

\section{PEMIKIRAN A. MUKTI ALI DALAM KEBIJAKAN PENDIDIKAN ISLAM INDONESIA}

\begin{abstract}
Abstrak
Tujuan penelitian ini adalah mendeskribsikan implikasi pemikiran Mukti Ali dalam kebijakan pendidikan Islam di Indonesia. Penelitian ini menggunakan metode kualitatif kepustakaan. Penelitian ini menympulkan bahwa pemikiran kebijakan Mukti Ali meliputi: a) Pembenahan lembaga pendidikan islam, b) Modernisasi lembaga pesantren, c) Pembenahan lembaga pendidikan tinggi Islam atau institut agama Islam negeri, d) Peningkatan mutu pendidikan IAIN. Mukti Ali menggunakan pendekatan integral dan interdepamental dalam menentukan kebijakan pendidikan islam selama menjabat Menteri Agama. SKB 3 menteri yang diterbitkan pada masa menteri agama Mukti Ali dikembangkan pada tahun 1986 melalui pilot projet MAN-PK, sehingga pendidikan Islam khususnya madrasah mulai nampak perkembangannya. Pada tahun selanjutnya dikeluarkan UUSPN No. 2 Tahun 1989 sampai pada UUSPN No.20 Tahun 2003 menjadi landasan kebijakan yang menekankan bahwa pendidikan agama berhak diterima oleh setiap peserta didik baik ditingkat dasar, menengah dan perguruan tinggi.
\end{abstract}

kata kunci: pemikiran, kebijakan pendidikan, lembaga pendidikan Islam 


\section{Pendahuluan}

Di Indonesia, kebijakan yang mengatur sistem pendidikan di era kemerdekaan hingga sekarang mempunyai banyak perubahan. Tidak hanya pendidikan secara umum, akan tetapi pendidikan agama juga memiliki berbagai perubahan. Setelah kemerdekaan indonesia, penyelenggara pendidikan agama mendapatkan perhatian serius dari pemerintah. Lembaga pendidikan Islam saat itu diberikan bantuan tuntunan dan material dari pemerintah sebagai upaya nyata bahwa madrasah dan pesantren merupakan bagian dari pendidikan nasional.

Pasca kemerdekaan pada masa Orde Baru, pemerintahan memandang bahwa agama mempunyai kedudukan dan peranan sangat penting dan strategis. Peran utama agama sebagai landasan spiritual, moral dan etika dalam pembangunan nasional, agama juga berpengaruh untuk membersihkan jiwa manusia dan kemakmuran rakyat. ${ }^{1}$ Agama sebagai sistem nilai seharusnya dipahami dan diamalkan oleh setiap individu, warga dan masyarakat hingga akhirnya dapat menjiwai kehidupan bangsa dan negara.

Penanaman nilai agama dalam pendidikan Islam mengalami pengembangan sejak pergantian menteri agama ke Prof. Dr. H. A Mukti Ali, ia melakukan banyak pembaruan serta inovasi di pendidikan Islam. Pada masa Mukti Ali menjabat sebagai menteri Agama muncul istilah, "Pembanguan manusia dan masyarakat Indonesia seutuhnya". Konsep " pembangunan manusia seutuhnya", bertitik tekan pada aspek manusia dengan religiositasnya. ${ }^{2}$

Dalam kapasitasnya sebagai seorang menteri agama, Mukti Ali banyak mengeluarkan kebijakan-kebijakan penting. Di antaranya adalah usaha Mukti Ali untuk menjaga semangat kerukunan antar umat beragama. ${ }^{3}$ Dimana ketika itu telah melawati konflik Islam-kristen dan Islam komunis. Selain itu, lahirnya surat keputusan bersama (SKB) Menteri Agama, Menteri P\&K dan Menteri Dalam Negeri, atau yang dikenal SKB tiga menteri, No.6 Tahun 1975, dan No. 037/U/a975, membawa penagruh besar terhadap lembaga pendidikan Islam, terlebih lagi tentang kebijakan modernisasi pesantren. Mukti Ali mempunyai harapan besar jika menjaga kemandirian pesantren dengan mempertahankan sistem atau bahkan kurikulum yang sudah berjalan, nantinya membawa pesantren ke pusat perhatian Orde Baru sangat besar. ${ }^{4}$

\footnotetext{
${ }^{1}$ Mahmud Yunus, Sejarah Pendidikan Islam, (Jakarta: Mutiara Sumber Widya, 1995), 133.

${ }^{2}$ Misjaya, "Pemikiran Pendidikan Muti Ali" dalam https://www.academia.edu/6855810/

Pemikiran_pendidikan_Mukti_Ali_REVISI (22 Maret 2017).

3 Rimbun Natamarga, "Mengubah dan Membentuk IAIN: Profil Ringkas Menteri Mukti Ali" dalamhttps://www.academia.edu/4026938/MENGUBAH_DAN_MEMBENTUK_IAIN_PROFIL_RINGKAS_ME

${ }^{4}$ Misjaya, "Pemikiran Pendidikan Muti Ali" dalam https:/www.academia.edu/6855810/

Pemikiran_pendidikan_Mukti_Ali_REVISI (22 Maret 2017).
} NTERI_MUKTI_ALI (22 Maret 2017). 
Berbagai kebijakan muncul sebagai pembaruan pada masa Mukti Ali memberikan perubahan terhadap dunia pendidikan Islam di Indonesia. Sebuah pemikiran kontemporer dan inovasi yang mempengaruhi beliau sebagai pimpinan membuat ruang peningkatan mutu pendidikan Islam. Sebagaimana pernyataan beliau dalam dalam tulisan renungannya terhadap kritik dialog antar agama, "Peningkatan pendidikan teknologi dan pendidikan dalam lapanganlapangan lain adalah soal lain yang kini sedang diusahakan oleh dunia Islam". 5 Dengan pernyataan tersebut, Mukti Ali mempunyai visi serta tujuan membawa dunia Islam khususnya pendidikan Islam di Indonesia memberikan kontribusi besar terhadap tantangan problematika Islam.

\section{Kebijakan Pemerintah terhadap Pendidikan Islam}

Secara historis lembaga pendidikan Islam tertua yang ada di Indonesia adalah pesantren. Terlepas dari pengaruh Hindu-Budha atau Arab, pesantren merupakan produk interaksi dan akulturasi Islam dengan budaya dalam konteks budaya asli. ${ }^{6}$ Sebelum kedatangan bangsa Eropa -termasuk Belanda- pendidikan Islam sudah ada dan mulai berkembang ke seluruh pelosok tanah air. Walaupun pelaksanaannya masih sangat sederhana jika dibandingkan dengan perkembangan setelah kedatangan bangsa Belanda. Pendidikan Islam berjalan dan berkembang siring dengan dakwah dan penyebaran Islam itu sendiri, baik dikalangan masyarakat maupun istana raja-raja. Pendidikan Islam pada saat itu mengambil bentuk halaqah dan tatap muka perorangan di mushalla, masjid, maupun pesantren.

Ketika Belanda datang pendidikan Islam mulai mengalami hambatan. Rintangan dan tantangan untuk berkembang lebih maju seiring dengan perkembangan dan kemajuan zaman itu terutama ketika dihadapkan dengan persaingan melawan kristenisasi yang justru dilakukan oleh kaum penjajah mulai dari bangsa Portugis hingga Belanda. Belanda membuat berbagai peraturan dan kebijakan yang intinya menghambat dan menghalangi perkembangan dan kemajuan pendidikan Islam.

Kebijakan-kebijakan pemerintah terhadap pendidikan Islam mulai tampak dari pemerintahan kolonial, awal dan pasca kemerdekaan hingga masuknya Orde Baru. Pada masa ini kebijakan pemerintah terhadap pendidikan Islam mempunyai kesan mengenyampingkan, memberikan batasan bahkan hampir menghapus sistem pendidikan Islam karena alasan "Indonesia bukanlah negara Islam". Akan tetapi, berkat dedikasi yang tinggi dari tokoh-tokoh pendidikan Islam pada masa itu, akhirnya berbagai kebijakan tersebut mampu teredam untuk

\footnotetext{
${ }^{5}$ Mukti Ali, Dialog Antar Agama, (Jogjakarta: yayasan Nida, 1970), 35.

${ }^{6}$ A. Timur Djaelani, Kebijaksanaan Pembinaan Kelembagaan Agama Islam, Jakarta: Dirjen Pembinaan Kelembagaan Agama Islam, 1982, h. 60.
} 
sebuah tujuan idealisasi pendidikan Islam yang terdapat dalam UU Republik Indonesia No 20 Tahun 2003, yaitu “ Pendidikan nasional berfungsi mengembangkan kemampuan dan membentuk watak serta peradaban bangsa yang bermartabat dalam rangka mencerdaskan kehidupan bangsa, bertujuan untuk berkembangnya potensi peserta didik agar menjadi manusia yang beriman dan bertakwa kepada Tuhan Yang Maha Esa, berakhlak mulia, sehat, berilmu, cakap, kreatif, mandiri, dan menjadi warga negara yang demokratis serta bertanggung jawab". 7 Suatu perjalanan panjang untuk mencapai idealisasi tersebut, sehingga sejak masa pra kemerdekaan hingga era reformasi ini pendidikan Islam mengalami berbagai perkembangan. Berbagai rintangan dan kelemahan pendidikan Islam sedikit demi sedikit telah menemukan penyelesaiannya, oleh karena itu dibutuhkannya pemikiran dan kebijakan strategis yang menjadikan pendidikan Islam semakin lebih baik.

Sistem dan kebijakan pendidikan yang kurang tertata mempuyai dampak pada lembaga pendidikan, khususnya lembaga pendidikan Islam yang mempunyai kelemahan di segala aspek. Diantaranya kelemahan tersebut : Kelemahan sumber daya manusia (SDM), manajemen maupun dana, Kurang mampu mengoptimalkan lembaga pendidikan secara idealnya, Belum mampu mewujudkan lembaga pendidikan yang transformative, Adaptasi terhadap era reformasi, Lembaga pendidikan Islam masih kurang diminati masyarakat. ${ }^{8}$ Dari berbagai kelemahankelemahan tersebut, membawa persoalan tersendiri dalam idealisme pendidikan Islam di Indonesia. Sebagai bangsa yang memegang amanat dan pembangun manusia seutuhnya, sudah tugas bagi seluruh rakyat Indonesia membangun kembali idealisme pendidikan yang berlandaskan dalam pembukaan Undang-Undang Dasar 1945. Dari hal tersebut ada dua faktor yang sangat mempengaruhi dari kebijakan pendidikan Islam selama ini.

Faktor Agama, -dalam proses pembudayaan manusia keberadaan pendidikan- mutlak diperlukan. Bukan saja karena ia merupakan produk sejarah dan masyarakat, melainkan juga karena peranannya yang asasi dalam pembentukan hari depan. Di atas peranannya ini terletak tugas dan tanggung jawab kultural edukatif terhadap anak didik dan masyarakat. Visi pendidikan Islam sesungguhnya melekat pada visi ajaran Islam itu sendiri yang terkait dengan visi kerasulan para Nabi, mulai dari visi kerasulan Nabi Adam AS. hingga kerasulan Nabi

\footnotetext{
${ }^{7}$ UU Sisdiknas Tahun 2003.

${ }^{8} \mathrm{https}: / /$ mpiuika.wordpress.com/2009/11/21/makalah-diskusi-analisis-kebijakan-pendidikan-islamkelompok-3/ (diakses pada tanggal 18 Agustus 2017).
} 
Muhammad SAW., yaitu membangun sebuah kehidupan manusia yang patuh dan tunduk kepada Allah SWT. serta membawa rahmat bagi seluruh alam. ${ }^{9}$

Faktor Ideologi Negara mempertemukan antara pendidikan Islam dan pendidikan nasional Indonesia, keduanya tidak dapat dipisahkan. Hal ini dapat ditelusuri dari dua segi: Pertama, dari konsep penyusunan sistem pendidikan nasional Indonesia itu sendiri. Kedua, dari hakikat pendidikan Islam dalam kehidupan beragama kaum muslimin di Indonesia. Penyusunan suatu sistem pendidikan nasional harus mementingkan masalah-masalah eksistensi umat manusia pada umumnya dan eksistensi bangsa Indonesia pada khususnya baik dalam hubungannya dengan masa lampau, masa kini dan kemungkinan-kemungkinan perkembangan masa depan. ${ }^{10}$

\section{A. Mukti Ali; Kebijakan Berbasis Metodologi Studi Islam}

A. Mukti Ali mempunyai segudang pemikiran tentang agama, negara, pendidikan, politik, dan kemasyarakatan, telah menjadi lapisan sejarah ke- Islaman, ke-Indonesiaan yang sangat luas dan tidak dapat tergantikan oleh siapa saja. Sebagai seorang intelektual, yang memiliki peran di Departemen Agama tidak membuat A. Mukti Ali kehilangan semangat berkarya. Ia melakukan banyak pembaharuan saat beliau menjabat sebagai Menteri Agama. A. Mukti Ali memunculkan istilah, "Pembanguan manusia dan masyarakat Indonesia seutuhnya". Konsep "pembangunan manusia seutuhnya", bertitik tekan pada aspek manusia dengan religiusitasnya. Dalam pandangannya, ia menekankan pembangunan ekonomi saja hanya akan menyababkan tumbuh suburnya kapitalisme dan imperialisme. Sedangkan dengan konsep "pembangunan masyarakat seutuhnya", diharapkan diskriminasi pembangunan antar kelompok etnis dan daerah dapat dihindari serta membangun manusia dari segala aspek yang di awali dalam pendidikan.

A. Mukti Ali juga memiliki gagasan pembaharuan di IAIN yang juga digulirkannya. Ketika menjabat sebagai Menteri Agama, berbagai kesempatan dalam forum yang diikuti, ia banyak mengkritisi beberapa kelemahan IAIN, yakni dalam penguasaan bahasa asing selain Arab (khususnya Ingris), minat ilmu, dan metode penelitian ilmu Islam. Kelemahan pertama menyebabkan banyak orang tidak dapat mengakses kajian sumber islam yang berasal dari bahasa Inggris. Padahal, kajian sumber Islam yang berbahasa inggris itu banyak tersebar di nergeri Eropa dan Amerika, sebagian juga ditulis oleh ilmuwan muslim. Selain itu, efek peguasaan bahasa asing, pads umumnya bahasa Inggris bagi intelektual muslim di negara kita

\footnotetext{
${ }^{9}$ Ibid.,

${ }^{10}$ Ibid.,
} 
menjadikan pikiran keislaman para sarjana tidak banyak bergema di dunia internasional. Kalau pun ada, hanya sebatas negeri yang berbahasa melayu. Untuk mengatasinya, A. Mukti Ali membangun pusat studi bahasa di setiap IAIN. Adapun untuk mengatasi kelemahan kedua dan ketiga, pintu belajar ke luar negeri, ke Timur Tengah dan Barat, harus dibuka lebar -lebar. ${ }^{11}$ Dengan harapan membuka pintu belajar keluar negeri dapat memberikan wajah baru serta keilmuan yang lebih ter-update yang lebih relevan dengan situai kondisi di era modernisasi.

Di bidang Sosial - Keagamaan, A. Mukti Ali, menghadapi berbagai persoalan modernitas orde baru yang masuk dalam kehidupan agama, ia mengeluarkan beberapa kebijakan tentang ide pembaharuan yang berangkat dari penghayatan panjang karena pada dasarnya latar belakang beliau dari kalangan akademisi. Diantaranya; menyelanggarakan lomba MTQ di tingkat nasional yang diadakan secara tahunan, ${ }^{12}$ kemudian mengadakan Undang - Undang No 1 Tahun 1974 tentang perkawinan. ${ }^{13}$ Dengan pengalaman yang panjang berkaitan dengan dunia keagamaan itu, maka ia memiliki pemahaman yang mendalam dalam hal studi islam. Dan tidak perlu diragukan lagi berkenaan dengan keilmuannya tersebut. Selain itu salah satu bentuk buah fikir dari A. Mukti Ali tentang gagasannya untuk mensponsori berdirinya Majelis Ulama' Indonesia (MUI) pada akhir 1975. Dan tidak lama setelah itu ia melihat berbagai lembaga keagamaan yang dimiliki komunitas agama di Indonesia juga telah berdiri. Dewan gereja Indonesia (DGI) milik orang Protestan, MAWI milik Katolik, Walubi milik umat Buddha, dan PHDI milik Hindu. ${ }^{14}$

Kebijakan "menghidupkan gairah beragama" ini berjalan seiring dengan perjuangan gigih A. Mukti Ali untuk mengajak komunitas - komunitas agama di Indonesia agar saling toleran, menghormati dan berdialog. ${ }^{15}$ Dari sini dapat terlihat departemen agama yang di bawah kepemimpinan A. Mukti Ali mengedepankan program pembinaan hidup beragama. Membangun sebuah peradaban tentu tidaklah mudah, membutuhkan proses yang sangat panjang dalam kesempurnaan akan sebuah pencapaian. Agar mencapai kesempurnaan dalam pencapaiannya, diperlukan upaya dan strategi dalam pembangunan. Pembangunan tidak sebatas individu yang mengedepankan materiil maupun non-materiil. Akan tetapi pembangunan disini merupakan

\footnotetext{
${ }^{11}$ Ensiklopedi Islam, (Jakarta: PT. Ikhtiar Baru Van Hoeve, 2005), 99

${ }^{12}$ Berdasarkan surat keputusan bersama (SKB) antara Menteri Agama dengan Menteri Dalam Negeri No 19 Tahun 1977 mengenai pengembangan Tilawati Qur'an.

${ }^{13}$ Ali Munhanif, prof. Dr. A. Mukti Ali; Modernisasi Politik Keagamaan Orde Baru, (Portal Kementerian Agama, 1997), $306-310$.

${ }^{14}$ Ali Munhanif, prof. Dr. A. Mukti Ali; Modernisasi Politik Keagamaan Orde Baru, (Portal Kementerian Agama, 1997), 287.

$47-48 .{ }^{15}$ Mukti Ali, Ilmu Perbandingan Agama di Indonesia (Yogyakarta, IAIN Sunan Kalijaga Press, 1990),
} 
perubahan dari yang belum baik menjadikan lebih baik pencapaiannya. Dalam kaitan ini Ginanjar Kartasasmita memberikan pemaknaan sederhana mengenai pembangunan adalah suatu proses ke arah yang lebih baik melalui uapaya yang dilakukan secara terencana. ${ }^{16}$ Dari hal tersebut pembangunan yang ideal merupakan pembangunan yang dilakukan secara totalitas dan mempunyai perencanaan yang matang.

Tokoh yang telah banyak mendedikasikan keilmuan melalui tindakannya untuk mengembangkan pendidikan Islam di Indonesia salah satunya ialah Mukti Ali. Dengan menjabat dalam jajaran penting dalam pemerintahan, beliau banyak melakukan pembangunan dan perkembangan yang strategis dari mengasah pola pikirnya menjadi sebuah ide yang kemudian diaplikasikan melalui kebijakan-kebijakannya untuk perkembangan dan kemajuan pendidikan Islam di Indonesia. Sebagai seseorang yang menjabat dalam pemerintahan pasti mempunyai pandangan dalam hal pembangunan. Pada saat menjabat sebagai menteri agama, Mukti Ali mempunyai pandangan bahwa pembangunan bukan hanya ekonomi, sosial dan rohani saja, akan tetapi pembangunan manusia seutuhnya. ${ }^{17}$ Maksud Mukti Ali disini, mengupayakan bahwa pembangunan tidak terbatas dan dilakukan secara menyeluruh dari segala aspek, melalui berbagai pendeketan-pendekatan dari multidisipliner keilmuan. Bentuk dari hal tersebut adalah ilmu pengetahuan dan pendidikan yang menjawab problematika modernisasi yang semakin banyak bermunculan. Secara konseptual pendidikan islam segala jawaban akan pertanyaan zaman tidak terlepas dari sumber ajaran islam yaitu Al Qur'an dan Hadist.

Mukti Ali dalam buku karangan Damami menjelaskan bahwa "pendidikan agama yang terpenting bagi keluarga terutama anak-anak adalah mendisiplinkan mereka mendirikan sholat dan dapat membaca al-Qur'an dengan fasih dan memahaminya. ${ }^{18}$ Konsep pendidikan menurut Mukti Ali adalah bagaimana seorang pelajar dapat bersikap disiplin terhadap ibadah dan kewajibannya dalam menuntut ilmu. Itu semua dilakukan bukan atas dasar untuk mendapatkan pujian ataupun nilai yang baik, akan tetapi murni dari dalam hati lillahi ta'ala. Selain bersumber pada Al Qur'an dan Hadist, konsep pendidikan islam tidak terlepas dari UUD 1945, Indonesia adalah Negara berideologikan Pancasila, dimana terdapat banyak keaneragaman suku, bahasa, agama, adat dan sebagainya. Mukti Ali berangkat sebagai Menteri Agama tentu tidak hanya fokus pada perkembangan pendidikan Islam saja, akan tetapi seluruh agama yang menjadi ciri Depatemen Agama juga merupakan dalam tanggung jawab Menteri Agama. Pembukaan UUD

\footnotetext{
${ }^{16} \mathrm{https}$ ///arifcintaselvia.wordpress.com/kuliah/teori-pembangunan/pembangunan-itu-apa/ (diakses pada tanggal 20 agustus 2017)

${ }^{17}$ Mukti Ali, Agama dan Pembangunan di Indonesia, 39.

${ }^{18}$ Mohammad Damami, dkk, Lima tokoh IAIN Sunan Kalijaga Yogyakarta: Prof. Dr. H. A. Mukti Ali,
} M.A, 231. 
1945 yang menjadi dasar negara Indonesia, di dalamnya tercantum kalimat "Mencerdaskan kehidupan bangsa dan ikut mentertibkan kehidupan dunia”. Merupakan dasar bahwasannya UUD 1945 sangat mengutamakan pendidikan sebagai pembentuk generasi masa depan yang produktif dan dapat bersaing di dunia dan dapat terlibat dalam upaya untuk mentertibkan kehidupan di dunia ini. Tidak terlepas dari UUD 1945, makna pendidikan juga tercantum dalam UU Sisdiknas No.20 Tahun 2003, yang menyebutkan bahwa pendidikan merupakan usaha sadar dan terencana untuk mewujudkan suasana belajar dan proses pembelajaran agar peserta didik secara aktif mengembangkan potensi dirinya untuk memiliki kekuatan spiritual keagamaan, pengendalian diri, kepribadian, kecerdasan, akhlak mulia, serta keterampilan yang diperlukan dirinya, masyarakat, bangsa dan Negara. ${ }^{19}$

Pendidikan Nasional yang diharapkan di dalam Undang-Undang tersebut, dapat diartikan sebagai pendidikan yang berdasarkan pada ideologi Pancasila dan UUD 1945 yang berakar pada nilai-nilai agama, kebudayaan dan menjawab tuntutan perubahan zaman. Bukti perubahan dalam pendidikan antara lain adalah adanya sistem pendidikan yang berhasil. Sistem pendidikan merupakan keseluruhan komponennya yang saling terkait dan terpadu dalam tujuan pendidikan. Tujuan pendidikan nasional dalam sistem pendidkan Nasional adalah berkembangnya potensi peserta didik agar menjadi manusia yang beriman dan bertakwa kepada Tuhan Yang Maha Esa, berakhlak mulia, sehat, berilmu, cakap, kreatif, mandiri, dan menjadi warga negara yang demokratis serta bertanggung jawab. Selain itu pendidikan bagi negara yang berkembang harus lebih membangkitkan pada masanya kesadaran terhadap dirinya dan hakhaknya akan pentingnya pendidikan. ${ }^{20}$

Pandangan pendidikan islam yang sangat diunggulkan Mukti Ali ketika menjabat sebagai Menteri Agama tidak terlepas dari pengalaman beliau yang berlatar belakang pesantren yang selalu mengedepankan dasar sumber ajaran islam. Namun beliau juga tidak melupakan bahwasannya ideologi dan UUD 1945 sebagai cita-cita bangsa merupakan bagian terpenting dalam segala keputusan kebijkan yang telah diambilnya. Pendidikan islam seutuhnya tidak akan terlepas dari bagaimana seseorang belajar memahami agama islam itu sendiri. Dari mengenal Al-Qur;an dan hadist hingga hal yang bersifat ilmiah sekalipun. Pemahaman tersebut membutuhkan metodologi yang tepat dan relevan. Koentjaraningrat menyatakan metode adalah suatu hal yang terdapat dalam aspek kelimuan yang diletakkan pada masalah sistem, dalam

\footnotetext{
${ }^{19}$ Undang-Undang Pemerintah Republik Indonesia tahun 2003 mengenai Sitem Pendidikan Nasional.

${ }^{20}$ Renungan Pendidikan dan Pembangunan yang neyatakan tidak ada sesuatu yang lebih penting bagi pembangunan melebihi pendidikan. A. Mukti Ali, Doalog antar Agama. 89.
} 
makna metode yang dapat dipahami sebagai hubungan upaya ilmiah yang menyangkut masalah kerja yang digunakan untuk memahami obyek yang menjadi sasaran ilmu yang bersangkutan. ${ }^{21}$ Jadi, upaya ilmiah yang mencapai pemahaman dan bekerja secara sistematis dapat dipahami sebagai metode.

Dalam mempelajari studi agama, Mukti Ali memiliki beberapa metode yang dianggap tepat dan relevan.Pendekatan Sosio-Historis, pendekatan ini merupakan perpaduan antara aspek sosiologi dan sejarah yang melekat di dalam penggunaannya. Dalam hal ini, Mukti Ali melihat aspek sosial pada suatu masyarakat sangat penting untuk digunakan didalam pendekatan studi agama. Selain itu terdapat pula aspek historis yang menjadi bagian lain di dalam pendekatan ini. aspek historis digunakan Mukti Ali untuk melihat suatu fenomena berdasarkan sisi sejarahnya. Hal ini ditempuh guna mencapai pemahaman dalam menganalisa suatu ajaran atau fenomena kepercayaan serta kebudayaan berdasarkan waktu terjadinya. Berdasarkan penerapannya di dalam studi Islam, bila menggunakan pendekatan sosio-historis ini, Mukti Ali mengatakan di dalam bukunya yang berjudul Metode Memahami Agama Islam tertulis bahwa asbabun nuzul (Al Quran) adalah sebuah kesatuan yang mutlak bagi sebuah studi Al-Quran untuk dapat memahaminya secara mendalam. ${ }^{22}$ Menurut Mukti Ali Selain dalam studi Islam terdahulu, telah terdapat asbabun nuzul (Al-quran) dan asbababul wurud (hadits) yang menurutnya merupakan metode dasar dalam studi Islam. ${ }^{23}$ Dalam asbabun nuzul terdapat aspek pemahaman sosiohistoris yang melatarbelakangi mengapa suatu ayat tersebut turun. Dalam ilmu tafsir asbabun nuzul merupakan metode untuk memahami bagaimana riwayat suatu ayat Al-Quran turun.

Pendekatan Tipologi, Kemudian selain daripada pendekatan yang terdapat diatas, Mukti Ali juga menggunakan pendekatan tipologi. Dalam memahami studi agama, Mukti Ali menawarkan pendektan tipologi ini yang tentunya dapat diterapkan dalam studi Islam yang didalamnya berisikan lima aspek dalam mengidentifikasinya, yaitu: Aspek Ketuhanan, Dalam memahami studi agama, terutama Islam tentunya kita harus terlebih dahulu memahami konsepsi ketuhanannya. Bagaimana sifat ketuhanan dalam Islam kemudian kita bandingkan dengan agama lainnya. Aspek Kitab Suci, Yang kedua dalam memahami studi Islam tentunya dibutuhkan pemahaman mengenai Al-Quran sebagai sumber pedoman dan hukum bagi agama Islam. Aspek Kenabian, Dalam studi Islam dibutuhkan pula pemahaman mengenai sifat Muhammad sebagai Nabi dan menjadi utusan di dalam Agama Islam. Dalam hal ini Mukti Ali mementingkan aspek kenabian ini dalam studi Islam yang dimaksudkan bahwa aspek kenabian

\footnotetext{
${ }^{21}$ Koentjaraningrat. Metode-Metode Penelitian Masyarak, edisi Ketiga. Jakarta: Gramedia. 1994, 7

${ }^{22}$ Mukti Ali. Metode Memahami Agama Islam. Jakarta: Bulan Bintang 1991. 25

23 Ijtihad dalam Pandangan Muhammad Abduh. Jakarta: BulanBintang. 1990.
} 
ini penting untuk dikaji, namun bukan berarti bahwa agama islam adalah mohammedanisme sebagaimana orang-orang menyamakannya dengan Yesus Kristus, Budhisme yang dibawa Gautama Budha dan Confucianisme yang berasal dari pemikiran Confucius (Mukti Ali, 1991:49). Aspek Kondisi Kejayaan Nabi, Pada aspek ini dimaknai sebagaimana untuk membandingkan kondisi kejayaan atau turunnya seorang Nabi di suatu agama kemudian dipahami pada agama lain pula. Aspek Orang-orang Terkemuka, Hal ini dimaksudkan bahwa dalam memahami studi agama, kita perlu melakukan riset terhadap orang-orang terkemuka ini yang terdapat didalam agama tertentu. Misalnya di dalam Islam, kita tentunya akan mempelajari bagaimana kepemimpinan pasca Rasulullah wafat yang menghasilkan khulafaur Rasyidin sebagai kajian aspek orang-orang terkemuka tersebut. ${ }^{24}$

Pendekatan Scientific dan Doctrine, dalam pendekatan ini, Mukti Ali ingin menerapkan metode ilmiah yang disatukan dengan doktrin atau ajaran-ajaran yang terkandung dalam suatu agama, khususnya dalam studi Islam. Dalam hal ini, Mukti Ali ingin mencoba menerapkan agar metode ilmiah dapat dijadikan alat untuk meneliti suatu agama. Contoh implikasi dalam pemikiran Mukti Ali ini terlihat dari cara beliau mencoba mengembangkan pendidikan madrasah serta Institut Agama Islam agar sejajar dengan institusi pendidikan yang umum dengan catatan bahwa keduanya mampu menerapkan metode ilmiah. Pendekatan ini dinilai revolusioner karena Mukti Ali berusaha merubah perspektif yang telah lama terbangun didalam ajaran ulama-ulama terdahulu yang hanya memahami ajaran Islam hanya dari segi dogma dan doktrin saja. Maka dari itu beliau berusaha menggabungkan doktrin tersebut dengan metode ilmiah agar sebuah studi dikatakan mampu memenuhi kriteria sebuah pengetahuan ilmiah.

\section{Kebijakan Publik Pada Masa Mukti Ali}

Beberapa kebijakan penting dikeluarkan oleh A. Mukti Ali ketika menjabat sebagai menteri agama. Beberapa kali beliau mengembangkan wacana keagamaan di Indonesia dengan reorientasi total hampir di seluruh aspek kehidupan bermasyarakat. Ia memulai gerakannya dari perumusan konsep Negara modern yang relevan bagi kultur keagamaan Indonesia, pembaharuan pemikiran, dialog antar umat beragama, modernisasi lembaga keagamaan, hingga pembaharuan kurikulum lembaga pendidikan Islam. Beberapa kebijakan penting yang pernah dikeluarkan oleh A.Mukti Ali diantaranya ialah usaha A.Mukti Ali untuk menjaga gairah semangat beragama.

\footnotetext{
${ }^{24}$ Mukti Ali. Metode Memahami Agama Islam. Jakarta: Bulan Bintang 1991. 37-44
} 
Serta pembersihan citra Kementrian Agama sebagai alat perjuangan politik golongan Islam tertentu. Dalam hal lain, A.Mukti Ali pernah menyatakan bahwa Indonesia bukanlah negara teokrasi, bukan pula negara sekuler. Sebagai Menteri Agama, A. Mukti Ali pernah mengupayakan adanya rasionalisasi Depag sebagai lembaga yang bertugas membangun manusia Indonesia seutuhnya.

A.Mukti Ali pernah mempopulerkan konsep manusia Indonesia seutuhnya yaitu kriteria pembangunan jasmani dan rohani manusia yang tentunya mensyaratkan adanya unsur iman dan takwa kepada Tuhan Yang Maha Esa. Ia juga memasukkan pembangunan di bidang agama dalam Garis-garis Besar Haluan Negara (GBHN). Untuk perkembangan IAIN, A.Mukti Ali menanamkan kesadaran bersama bahwa IAIN memiliki tugas yang sama dengan perguruan tinggi lainnya. Artinya, IAIN harus melaksanakan Tridharma Perguruan Tinggi yang meliputi usaha pengajaran dan pendidikan, penelitian serta pengabdian masyarakat. Kemudian, A.Mukti Ali adalah sosok terkemuka yang menjadi sponsor berdirinya Majelis Ulama Indonesia (MUI) pada bulan Juli 1975. MUI diproyeksikan sebagai lembaga yang memiliki fungsi utama sebagai sumber memberi pertimbangan kepada umat Islam di Indonesia serta pihak pemerintah yang terkait dengan permasalahan agama dan masyarakat. Majelis Ulama Indonesia (MUI) masuk dalam sejarah bangsa Indonesia ketika tengah berada di era kebangkitan kembali, setelah selama tiga puluh tahun sejak kemerdekaan bangsa ini terserap dalam perjuangan politik, baik di dalam negeri maupun di dalam forum Internasional. Sehingga dalam hal ini kurang mempunyai kesempatan untuk membangun kembali menjadi bangsa yang maju dan berakhlak mulia. ${ }^{25}$ Lahirnya Majelis Ulama Indonesia (MUI) tidak terlepas dari faktor internal dan eksternal. Faktor internal ialah kondisi umat Islam dan bangsa Indonesia seperti rendahnya pemahaman dan pengalaman agama. Lebih daripada itu, kemajemukan dan keragaman umat Islam dalam alam pikiran keagamaan, organisasi sosial, dan kecendrungan aliran dan aspirasi politik selain dapat merupakan kekuatan, tetapi sering juga menjelma menjadi kelemahan dan sumber pertentangan di kalangan umat Islam sendiri. ${ }^{26}$ Sedangkan faktor eksternal ialah suasana yang mengintari umat Islam dan bangsa Indonesia yang menghadapi tantangan global yang sangat berat. $^{27}$

Terakhir, ketika A. Mukti Ali menjabat sebagai menteri agama. Terdapat satu kebijakan yang menjadi pusat perhatian partisipasi atau concern islam secara luas, yakni ketika

\footnotetext{
${ }^{25}$ Pedoman Penyelenggaraan Organisasi Majelis Ulama Indonesia Edisi Revisi 2011 Hasil Rakernas MUI Tahun 2011, (Sekretariat Majelis Ulama Indonesia Pusat, 2011), 4.

${ }^{26}$ Profil Majelis Ulama Indonesia: Pusat dan Sumatera Utara, (Dewan Pimpinan Majelis Ulama Indonesia Sumatera Utara, 2006), 8.

${ }^{27}$ Ibid., 9.
} 
keluarnya Undang-Undang No. 1 Tahun 1974 tentang perkawinan. Proses dalam pengajuan RUU ini membawa pemerintah orde baru, khususnya departemen agama ke dalam situasi politik dan psikologis yang mencekam. Sehingga A.Mukti Ali mendapat penolakan keras terhadap RUU tersebut. ${ }^{28}$ Beberapa hal yang menjadikan pusat masalah dalam RUU ini terletak pada pasal 2 ayat 1 yang berbunyi; "Perkawinan adalah sah bila dilakukan di hadapan pegawai pencatat perkawinan, tercatat dan terdaftar dalam catatan perkawinan oleh pegawai tersebut, dan dilangsungkan menurut Undang-Undang ini sesuai ketentuan hukum perkawinan pihak-pihak yang melakukan perkawinan sepanjang tidak bertentangan dengan undang-undang." Pasal yangmuncul ini mendapatkan penolakan keras umat Islam, karena keabsahan perkawinan bukan tegantung kepada pegawai pemerintah. Pasal lain yang mengundang penolakan adalah Pasal 11 ayat 2, yang berbunyi: "Perbedaan karena kebangsaan, suku bangsa, Negara asal, tempat asal, agama/kepercayaan dan keturunan tidak merupakan penghalang perkawinan. "Pasal ini dipandang sebagai upaya untuk melegalkan pernikahan beda agama dan upaya pemurtadan umat Islam.

Beragam upaya dilakukan umat Islam untuk menyampaikan protes mereka, mulai dari menyurati pemerintah hingga aksi demonstrasi yang merebak hingga ke daerah. Protes mencapai puncaknya pada 27 September 1973, ketika Menteri Agama, A. Mukti Ali memberikan jawaban atas pemandangan umum fraksi-fraksi di DPR atas RUU tersebut. Ketika ia hampir selesai berpidato,32 Sekumpulan mahasiswa Muslim berteriak dan memegang spanduk-spanduk protes bertuliskan RUU Perkawinan adalah konsep kafire serta RUU

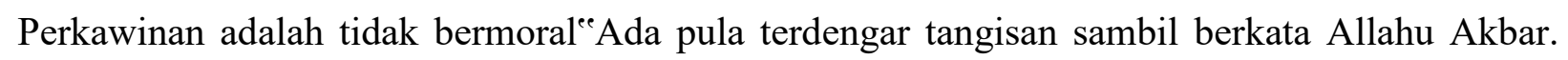
Menyadari situasi tak kondusif, Menteri Agama dan banyak anggota parlemen meninggalkan ruangan. Tak lama, sekitar 500 mahasiswa menduduki ruangan tersebut. Kegaduhan politik yang diakibatkan oleh RUU perkawinan mulai mereda setelah diadakan pendekatan dengan Presiden Soeharto. Intinya, pendekatan itu dimaksudkan untuk memberikan pengertian kepada presiden bahwa muatan RUU tersebut, benar-benar mengganggu akidah umat Islam. Dari situ A. Mukti Ali memprakarsai untuk berdialog dan lobi informal dengan pemuka-pemuka islam dan non islam untuk mencari penyelesaian di luar siding DPR. Dan melalui perdebatan yang panjang akhirnya pada tanggal 2 Januari 1974 disahkan menjadi UU No. 1 tahun 1974 tentang perkawinan. Namun, undang-undang ini mulai berlaku secara efektif pada tanggal 1Oktober

\footnotetext{
${ }^{28}$ Ali Munhanif, Prof. Dr. A. Mukti Ali; Modernisasi Politik Keagamaan Orde Baru, (Portal Kementerian Agama, 1997), 306.
} 
1975, alasan yang diberikan seperti tertulis dalam penjelasan umum Peraturan Pelaksanaannya (PP No. 9 Tahun 1975). Karena untuk pelaksanaan peraturan ini perlu langkah-langkah persiapan dan serangkaian petunjuk-petunjuk pelaksanaan dari beberapa Departemen atau Instansi yang terkait.

Berikut adalah kebijakan-kebijakan Mukti Ali dalam dunia pendidikan Islam di Indonesia. Modernisasi Lembaga Pesantren Sempat menjadi Menteri Agama pada masa Orde Baru, Mukti Ali melakukan beberapa pengamatan pendidikan di pesantren, yang mana terdapat 5 komponen pendidikan di dalamnya, yaitu: a. Pengajaran dan pendidikan agama. b. Ketrampilan sesuai dengan kemampuan dan kebutuhan masyarakat sekitar. c. Kepramukaan, dimana pendidikan dan disiplin agama dapat dilakukan dengan perantaraan kegiatan pramuka. Memang pramuka adalah organisasi pendidikan, diluar pendidikan sekolah dan diluar pendidikan keluarga, yang paling baik. d. Kesehatan dan olahraga. Ini perlu ditingkatkan di pondok pesantren yang kurang mengambil perhatian terhadap kesehatan dan olahraga ini. e. Kesenian yang bernafaskan Islam (Mukti Ali, 1987: 21).

Dalam hal modernisasi lembaga pesantren, Mukti Ali tetap menjaga kemandirian pesantren dengan mempertahankan sistem atau bahkan kurikulum yang sudah berjalan, keinginannya untuk membawa pesantren ke pusat perhatian pemerintah Orde Baru sangat besar. Melalui SKB Menteri Agama dan Menteri Pertanian No. 34 A tahun 1972, mengadakan program bersama dengan Departemen Pertanian untuk mengadakan pembinaan pondok pesantren dalam bidang pertanian dan perikanan. Kerja sama itu juga dilakukan dengan departemen-departemen lain, yang intinya ditujukan dengan untuk memberikan pembinaanpembinaan menejerial bagi pengelola lembaga pendidikan Islam (Abuddin, 2012: 352)

SKB Tiga Menteri, No. 6 Tahun 1975 dan No.037/U/a975 Surat Keputusan Bersama (SKB) Menteri Agama, Menteri Pendidikan dan Kebudayaan serta Menteri Dalam Negeri atau dikenal sebagai SKB Tiga Menteri, No. 6 Tahun 1975 dan No.037/U/a975. Dalam SKB Tiga Menteri tersebut ditegaskan: a. Agar ijazah madrasah di semua jenjang dapat mempunyai nilai yang sama dengan ijazah sekolah umum yang singkat b. Agar lulusan madrasah dapat melanjutkan ke sekolah umum setingkat dan lebih atas c. Agar siswa madrasah dapat berpindah ke sekolah umum yang setingkat, maka kurikulum yang diselenggarakan madrasah harus terdiri dari $70 \%$ pelajaran umum dan 30\% pelajaran Agama.

Melalui kebijakan SKB ini, paling kurang ada dua hal pending bagi masa depan pendidikan Islam di Indonesia. Pertama, dalam jangka integrasi pendidikan Islam ke dalam sistem pendidikan nasional. Kedua, dengan memasukkan kurikulum pelajaran umum dalam 
jumlah jam yang besar, diharapkan pembenahan madrasah untuk ditransformasikan menjadi lembaga pendidikan yang berorientasi pada pengembangan sumber daya manusia Muslim akan dapat diwujudkan. Dengan cara demikian, pengakuan masyarakat terhadap keberadaan lembaga pendidikan Islam di masa mendatang semakin kuat (Abuddin, 2012: 352-353).

\section{Kebijakan pendidikan islam}

Sosok Mukti Ali sebagai seorang pemikir dan intelektual muslim mempunyai peran tersendiri dalam perkembangan Islam di Indonesia. Mempunyai peran penting di pemerintahan pada masa orde baru tidak disia-siakan oleh beliau. Dengan mengedepankan semangat belajar agama dan pendidikan khususnya, ia mengajak masyarakat Indonesia lebih memahami hakhaknya sebagai manusia. Mukti Ali selalu mengajak masyarakat Indonesia bahwa pembangunan bukan hanya ekonomi, sosial dan rohani saja, akan tetapi pembangunan manusia seutuhnya. ${ }^{29}$ Pembangunan manusia yang sangat diidamkan Mukti Ali merupakan kesadaran seutuhnya pada diri setiap manusia akan hal bersifat intelektual, agama dan keyakinan. Ia juga berharap bahwa menjadi manusia harus bisa berkembang tidak hanya dari satu ilmu pengetahuan dan satu sudut pandang saja. Akan tetapi menyeluruh dari multidisipliner kelimuan yang saling berkaitan.

Sebagai sosok Menteri Agama, pandangan Mukti Ali terhadap pembangunan manusia seutuhnya merupakan ide pokok terbesar dalam sejarah pendidikan islam di Indonesia. Menurutnya, dengan pendidikan terhadap manusia pembangunan itu akan timbullah partisipasi dalam pembangunan. ${ }^{30}$ Hal ini dimaksudkan oleh bahwa pembangunan akan terealisasi jika pendidikan merupakan hal yang paling urgent dilaksanakannya. Sejauh ini pembaharuan di bidang pendidikan, khususnya pendidikan islam pada masa Mukti Ali tercatat ada berbagai perkembangan dan modernisasi mengenai pendidikan islam.Gagasan, pemikiran dan kebijakan beliau yang terkait dengan pendidikan islam, menurut Abuddin Nata ada empat poin penting. Hal tersebut yang dikemukakan beliau antara lain sebagai berikut. ${ }^{31}$

Kebijakan tentang pembenahan lembaga pendidikan Islam. Upaya yang dilakukan ini antara lain mengambil inisiatif dengan merencanakan kerjasama dengan departemen lain, khususnya departemen Pendidikan dan Kebudayaan. Pembenahan lembaga pendidikan Islam ini di landasi dari kegelisahan beliau melihat realita lembaga pendidikan islam yang kurang terbuka dengan dunia luar. Hal ini dirasakan beliau ketika mengalami perbedaan yang tampak signifikan

\footnotetext{
${ }^{29}$ Mukti Ali, Agama dan Pembangunan di Indonesia, 39.

${ }^{30}$ Ibid., 50

${ }^{31}$ Abuddin Nata, Pemikiran Pendidikan Islam dan Barat, (Jakarta: PT. Raja Grafindo Persada), 354.
} 
ketika belajar di pesantren, STI hingga di Universitas McGill. Ia merasa harus merubah keadaan yang dikatakan terbelakang akibat kebudayaan dan struktur masyarakat yang tradisional dan ditambah dengan warisan kolonialisme. ${ }^{32}$ Dengan melalui proses panjang dan hati-hati maka lahirlah SKB atau Surat Keputusan Bersama Tiga Menteri, No. 6 Tahun 1975 dan No.037/U/a975. ${ }^{33}$ Dalam SKB Tiga Menteri, ada beberapa hal yang ditegaskan di dalamnya, antara lain: a) agar ijazah madrasah di semua jenjang dapat mempunyai nilai yang sama dengan ijazah sekolah umum yang singkat; b) agar lulusan madrasah dapat melanjutkan ke sekolah umum setingkat dan lebih atas; c) agar siswa madrasah dapat berpindah ke sekolah umum yang setingkat, maka kurikulum yang diselenggarakan madrasah harus terdiri dari $70 \%$ pelajaran umum dan 30\% pelajaran Agama. Dengan demikian, status sosial lembaga pendidikan islam akan memperoleh tempat tersendiri di masyarakat Indonesia. Harapan terbesarnya dengan hal ini, pendidikan islam khususnya lembaganya harus memiliki eksistensi yang mempunyai sistem nilai tersendiri dan menjawab realitas kehidupan manusia. Dengan memasukkan kurikulum pelajaran umum dan mengintegrasikan ke dalam sistem pendidikan Nasional, pendidikan islam memiliki pengakuan yang kuat dan dapat mewujudkan pengembangan sumber daya manusia muslim.

Sebagai seorang santri Mukti Ali ingin membawa pesantren ke pusat perhatian pemerintahan Orde Baru. Meskipun Mukti Ali tetap berusaha menjaga kemandirian pesantren dengan mempertahankan sistem atau bahkan kurikulum yang sudah berjalan, ia menginginkan pembinaan manajerial pesantren dan menjadikan pesantren sebagai pendidikan kearifan lokal. Salah satu usahanya mengeluarkan SKB Menteri Agama dan Menteri Pertanian No. 34 A tahun 1972, mengadakan program bersama dengan Departemen Pertanian untuk mengadakan pembinaan pondok pesantren dalam bidang pertanian dan perikanan. Usaha lain yang dilakukan oleh Mukti Ali mengenai modernisasi pesantren adalah dengan melakukan beberapa pengamatan pendidikan di pesantren, yang mana terdapat 5 komponen pendidikan di dalamnya, yaitu: a) pengajaran dan pendidikan agama; b) Ketrampilan sesuai dengan kemampuan dan kebutuhan masyarakat sekitar; c) kepramukaan, dimana pendidikan dan disiplin agama dapat dilakukan dengan perantaraan kegiatan pramuka; d) kesehatan dan olahraga. Ini perlu ditingkatkan di pondok pesantren yang kurang mengambil perhatian terhadap kesehatan dan olahraga ini; e) Kesenian yang bernafaskan Islam. Mukti Ali sangat menginginkan Modernisasi pendidikan Islam, terutama pendidikan pesantren. Kepedulian beliau akan pendidikan pesantren,

\footnotetext{
${ }^{32}$ Mukti Ali, Agama dan Pembangunan di Indonesia, 51

${ }^{33}$ Ali Munhanif, Prof. Dr. A. Mukti Ali; Modernisasi Politik Keagamaan Orde Baru, (Portal Kementerian Agama, 1997), 313.
} 
ingin membawa pesantren lebih maju dari segi manajerial dan kearifan lokal. Dengan lima komponen tersebut pesantren mempunyai penyegaran yang luar biasa dalam menjawab berbagai tantangan dunia pendidikan modernisasi.

Kebijakan tentang pembenahan Institut Agama Islam Negeri (IAIN), Departemen Agama mencanangkan perluasan pendidikan tinggi bagi umat Islam, sebagaimana tercantum dalam Repelita I Tahun 1969 - 1973. Pada saat itu umat Islam secara berbondong-bondong baik atas nama yayasan agama, organisasi, pesantren atau pribadi, banyak mendirikan pendidikan tinggi Islam. Berdasarkan laporan Departemen Agama, disebutkan bahwa pada pertengahan tahun 1973, jumlah lembaga pendidikan tinggi Islam se Indonesia ada sekitar 112 IAIN, tersebar di seluruh pelosok anah air. Ada yang di kota besar, dan ada juga yang di kota kecamatan, bahkan di pedesaan. Dengan mempertimbangkan perkembangan ini, A. Mukti Ali berusaha meneliti kelayakan IAIN yang berjumlah besar saat itu. Berdasarkan Keputusan Direktur Pembinaan Perguruan Tinggi Agama (Bimperta) No. 32 Tahun 1975, hasilnya dari 112 IAIN hanya 13 lembaga yang terdapat di kota provinsi dan memenuhi syarat menjadi lembaga pendidikan tinggi agama, diberikan izin untuk beroperasi. Sementara itu, IAIN yang berada di kota kabupaten, seperti Cirebon, Serang, Malang, dan mataram, yang dirasa memenuhi syarat dijadikan IAIN cabang, secara administratif berada di bawah supervisi IAIN yang terdapat di kota provinsi. Kebijakan itu dipandang oleh Mukti Ali sebagai sesuatu yang mendasari rencana pengembangan IAIN selanjutnya. ${ }^{34}$ Dengan melakukan pembenahan IAIN, Mukti Ali menginginkan perubahan-perubahan yang dianggapnya ketinggalan zaman pada perguruan tinggi. Ia juga berharap pendidikan tinggi inilah jalan yang paling pendek untuk memperoleh pengetahuan. ${ }^{35}$ Maksudnya adalah dengan adanya perguruan tinggi ini sarana memperoleh ilmu pengetahuan lebih mudah dan efisisen menjawab tantangan persoalan yang akan datang.

Kebijakan peningkatan mutu Institut Agama Islam Negeri (IAIN), Kebijakan mengenai peningkatan mutu ini dilakukan dengan cara mengirim tenaga pengajar di IAIN untuk belajar ke luar negeri. Negara-negara yang dituju untuk progam ini antara lain Timur Tengah, Amerika Serikat, Belanda, dan Kanada. Menurut catatan Departemen Agama, hingga 1972, jumlah dosen IAIN dan pejabat Departemen Agama yang dikirim ke Barat ada sekitar 55 orang. ${ }^{36}$ Kebijakan ini merujuk pada Post Graduate Course yang pertama berhasil dengan baik dan salah satu

\footnotetext{
${ }^{34}$ Abuddin Nata, Pemikiran Pendidikan Islam dan Barat, (Jakarta: PT. Raja Grafindo Persada), 354

${ }^{35}$ Mukti Ali, Agama dan Pembangunan Islam di Indonesia, 114.

${ }^{36}$ Abuddin Nata, Pemikiran Pendidikan Islam dan Barat, (Jakarta: PT. Raja Grafindo Persada), 354
} 
tokohnya adalah Prof. T.M Hasbi Ashshiddieqy dan A. Mukti Ali. ${ }^{37}$ Sehingga progam peningkatan mutu ini terus dikembangkan dan didukung penuh pada saat Mukti Ali menjabat sebagai Menteri Agama. Pada dasarnya progam ini berusaha mengangkat pendidikan tinggi islam lebih maju dan membawa perubahan besar. Dengan segudang pengalaman diri di berbagai kesibukannya mengajar di beberapa Perguruan Tinggi Islam baik swasta maupun negeri, seperti Perguruan tinggi Islam Negeri (PTAIN) di Yogyakarta dan Akademi Dinas Ilmu Agama (ADIA) Jakarta. A. Mukti Ali juga mengajar di IAIN jakarta, Universitas Islam Djakarta (UID), dan IKIP Muhammadiyah. Dan pada tahun 1960, ia diangkat menjadi sekretaris Fakultas Adab IAIN Jakarta sambil mengajar bahasa Inggris. Kemudian pada tahun 1961, oleh Prof. H. Muchtar Yahya, Dekan Fakultas Ushuluddin IAIN Yogyakarta, diminta membuka Jurusan Perbandingan Agama selain Jurusan Pendidikan dan Filsafat yang lebih duluan ada di Fakultas Ushuluddin, dengan ketua jurusan beliau sendiri. ${ }^{38}$ Ia memiliki pandangan bahwa corak bangsa yang akan datang dapat diketahui dari corak universitas dan perguruan tinggi dewasa ini. ${ }^{39}$ Dengan Maksud, ia mengajak dari pengalamannya yang luas di dunia pendidikan tinggi, berharap bahwa kemajuan bangsa terletak pada kualitas pendidikan tinggi yang sedang berjalan saat itu, sehingga rendah dan tingginya pendidikan tinggi ada apa kualiatas administratif dan pendidikan tinggi itu sendiri. Selain itu mukti ali mempunyai harapan terbesar akan mutu pendidikan tinggi ini adalah mahasiswa yang harus siap menjawab persoalan-persoalan yang mungkin timbul 30 atau 40 tahun yang akan datang. ${ }^{40}$ Hal ini dimaksudkan agar orientasi pendidikan islam, akan terus terjaga dan mempunyai regenerasi yang mempunyai eksistensi kritis dalam dunia ilmu pengetahuan.

Berbagai kebijakan dan gagasan beliau mengenai pendidikan islam yang telah diuraikan diatas, tidak terlepas corak pemikiran pendidikan beliau yang telah lama dilaluinya dari pendidikan klasikal hingga modern, serta kiprah dan intelektual beliau dalam perjalanan dunia pendidikan khususnya. Sebagai seorang akademisi dan praktisi, Mukti Ali mempunyai visi dalam mengembangkan agama islam. lebih khususnya tentang pendidikan islam. Salah satu bukti dedikasi beliau dalam kebijakan pendidikan islam dilandasi dari pembangunan manusia seutuhnya. Ide membangun masyarakat Indonesia melalui pembangunan menyeluruh yang sesuai dengan hak dan kewajibannya. Mukti Ali dalam pembangunan manusia seutuhnya memerlukan pendekatan integral dan interdepamental. Dengan hal tersebut, diharapkan arah

\footnotetext{
${ }^{37}$ Mukti Ali, Agama dan Pembangunan Islam di Indonesia, 108

${ }^{38}$ Lukman, Studi Kritis Terhadap Konsep Perbandingan Agama Abdul Mukti Ali, (Tesis UIKA, 2013),

${ }^{39}$ Mukti Ali, Agama dan Pembangunan Islam di Indonesia, 114

${ }^{40}$ Ibid., 114
} 
tujuan akan pembangunan manusia seutuhnya lebih totalitas dan tepat guna. Diharapkan dari kebijakan yang memunculkan hal demikian masyarakat kita lebih transformatif dalam segala hal, khususnya pendidikan islam.

Kebijakan Reformasi Pendidikan Islam di Indonesia, secara penerapannya dipengaruhi oleh banyak faktor, salah satunya adalah kebijakan politik oleh pemerintah. Hal ini dapat dilihat dari perjalanan pendidikan Islam dari masa ke masa banyak terjadinya diskriminasi pendidikan Islam dari masa klonialisasi sampai Orde Baru. Sehingga akan sangat tampak kelemahan dan kekurangan pendidikan Islam, dan harus dilakukan perbaikan secara intensif oleh pemerintah.Salah satu bentuk reformasi pendidikan Islam yang terletak pada masa Orde Baru, yang mana pembaharuan tersebut dibawa oleh Menteri Agama Mukti Ali. Gagasan, pemikiran dan kebijakan beliau yang terkait dengan pendidikan islam, menurut Abuddin Nata ada empat poin penting antara lain : 1. Pembenahan lembaga pendidikan Islam, 2. Modernisasi Pesantren, 3.Pembenahan lembaga IAIN, 4. Peningkatan Mutu IAIN. ${ }^{41}$ Dalam hal ini pembaharuan yang dikeluarkan saat beliau saat itu membawa angin segar bagi dunia pendidikan islam saat ini.

Pengakuan terhadap madrasah yang dulu terdsikriminasi dan modernisasi pesantren yang menjadikan pengakuan bahwasannya pesantren merupakan pendidikan indigenous, ${ }^{42}$ serta perkembangan perguruan tinggi Islam dari STAIN menjadi IAIN hingga menajdi UIN. Selain itu, pada tahun 1986 diselenggarakan madrasah pilot project (MAN PK) yang mengikuti komposisi materi agama $70 \%$ dan materi umum $30 \% .^{43}$ Dengan harapan lulusan dari MAN PK ini membawa pembaharuan yang lebih besar untuk pelajar islam dari cita awal SKB tiga Menteri pada masa Mukti Ali yang komposisi kurikulumnya bertolak belakang. Sehingga sebelum memasuki dunia pendidikan tinggi pelajar muslim dari kalangan madrasah mempunyai dasar keagamaan yang kuat dengan sistem integrasi pendidikan Agama dan Umum.

Dengan adanya landasan hukum yang jelas, tercantum dalam UUSPN No. 2 tahun 1989 maupun UUSPN No. 20 Tahun 2003 menjadi landasan kebijakan yang menekankan bahwa pendidikan agama berhak diterima oleh setiap peserta didik baik ditingkat dasar, menengah dan perguruan tinggi. ${ }^{44}$ Hal ini membuat pendidikan islam semakin diakui dan terintegrasi dalam sistem pendidikan Nasional. Tidak hanya dari pendidikan formal seperti madrasah (MI, MTs,

\footnotetext{
${ }^{41}$ Abuddin Nata, Pemikiran Pendidikan Islam dan Barat, (Jakarta: PT. Raja Grafindo Persada), 354

42 pernyataan Nurcholis Madjid bahwa tidak perlu diragukan lagi terkait dengan sejarah pesantren sebagai pendidikan asli indegionus Indonesia

${ }^{43}$ M. Shabir U, Kebijakan Pemerintah dan PengaruhnyaTerhadap Pendidikan Islam di Indonesia, dalam Jurnal Lentera Pendidikan, Vol. 16 No. 2 Desember 2013, hlm. 169

${ }^{44}$ Samsul Nizar dan M. Syaifudin, Isu-isu Kontemporer Tentang Pendidikan Islam, (Jakarta: kalam Mulia, 2010), hlm. 245,
} 
MA), akan tetapi pendidikan non-formal (pesantren, dll) hingga in-formal sekalipun, mempunyai landasan pendidikan yang jelas arah serta tujuannya. Dengan demikian bentuk pembaharuan yang dikeluarkan pada masa Mukti Ali menjabat sebagai Menteri Agama membawa pengaruh besar pada pendidikan islam. tidak hanya yang berlandasan hukum saja, akan tetapi dari khazanah intelektual yang sangat luas membawa dampak luar biasa bagi pelajar dan mahasiswa muslim untuk menjawab tantangan 30-40 tahun problem yang akan datang.

\section{Kesimpulan}

Penelitian ini menyimpulkan beberapa poin. Mukti Ali menggunakan pendekatan integral dan interdepamental dalam kebijakannya. Ketiga, Kebijakan Reformasi Pendidikan Islam di Indonesia, secara penerapannya dipengaruhi oleh banyak faktor. Sehingga dengan menjadi menteri agama saat itu, beliau mengeluarkan SKB 3 meteri yang berguna dalam modernisasi lembaga pendidikan Islam. Selanjutnya kebijakan tersebut dikembangkan pada tahun 1986 yang diselelnggarakannya pilot projet MAN-PK, sehingga pendidikan Islam khususnya madrasah mulai nampak perkembangannya. Pada tahun selanjutnya dikeluarkan UUSPN No. 2 Tahun 1989 sampai pada UUSPN No.20 Tahun 2003 menjadi landasan kebijakan yang menekankan bahwa pendidikan agama berhak diterima oleh setiap peserta didik baik ditingkat dasar, menengah dan perguruan tinggi. Dan tidak terlepas juga pendidikan Islam dapat dilalui dengan pendidikan formal, non-formal dan informal. pembaharuan yang dikeluarkan pada masa Mukti Ali menjabat sebagai Menteri Agama membawa pengaruh besar pada pendidikan islam. tidak hanya yang berlandasan hukum saja, akan tetapi dari khazanah intelektual yang sangat luas membawa dampak luar biasa bagi pelajar dan mahasiswa muslim untuk menjawab tantangan 30-40 tahun problem yang akan datang. 


\section{Referensi}

Abdurrahman, Burhanuddin Daya, Djameeannuri (ed.). 1993. Agama dan Masyarakat; 70 tahun H. A. Mukti Ali. IAIN Sunan Kalijaga Prees. Yogyakarta.

Achmadi. 2005. Ideologi Pendidikan Islam; Paradigma Humanisme Teosentris. Pustaka Pelajar. Yogyakarta.

Achmadi. 2005. Ideologi Pendidikan Islam; Paradigma Humanisme Teosentris. Pustaka Pelajar. Yogyakarta

Ali, A. Mukti. 1991. Metode Memmahami Agama Islam. Bulan Bintang. Jakarta.

Ali, Mukti. 1965. Ilmu Perbandingan Agama, Sebuah Pembahasan tentang Metode dan Sistem. Yayasan Nida. Yogyakarta.

Ali, Mukti. 1970. Dialog Antar Agama. yayasan Nida. Jogjakarta.

Ali, Mukti. 1973. Agama dan Pembangunan di Indonesia.

Ali, Mukti. 1987. Beberapa Persoalan Agama Dewasa Ini. Rajawali Pers. Jakarta.

Ali, Mukti. 1990. Ijtihad dalam Pandangan Muhammad Abduh. Bulan Bintang. Jakarta.

al-Nahlawi, Abdurahman, terj. Herry Noer Ali. 1989. Prinsip-prinsip dan Metode Pendidikan Islam. CV. Diponegoro. Bandung.

Amin Syukur. 2000. Pengantar Study Islam. CV. Bima Sejati. Semarang.

Arifin, M. 2003. Ilmu Pendidikan Islam; Tinjauan Teoritis dan Praktis Berdasarkan Pendekatan Interdisipliner. Bumi Aksara. Jakarta.

Arifin, M. 2003. Ilmu Pendidikan Islam; Tinjauan Teoritis dan Praktis Berdasarkan Pendekatan Interdisipliner. Bumi Aksara. Jakarta.

Amin, H. A. (2021). GUARDIANS CONCEPT IN QUR'AN PERSPECTIVE . SHAKHSIYAH BURHANIYAH: Jurnal Penelitian Hukum Islam,6(1), 95 - 114. https://doi.org/10.33752/sbjphi.v6i1.1642

Al Amin, H. (2016). Tafsir Sufi Lata' if al-Isyarat. SUHUF, 9(1), 59-77.

Al Amin, H. (2014). Penciptaan Adam; Mendialogkan TafsiR Marah Labid dengan Teori Keadilan Gender. An-Nuha : Jurnal Kajian Islam, Pendidikan, Budaya Dan Sosial, 1(1), 17-44. Retrieved from 